\title{
Ethnopharmacological investigations of methanolic extract of Pouzolzia Zeylanica (L.) Benn
}

Md Solayman Hossain', M. Sohanur Rahman², A. H. M. Rahmatullah Imon³, Sinthia Zaman', A. S. M. Badrul Alam Siddiky ${ }^{1}$, Milon Mondal ${ }^{1}$, Abeer Sarwar ${ }^{4}$, Tamanna Binte Huq ${ }^{4}$, Bikash Chandra Adhikary ${ }^{5}$, Taslima Begum ${ }^{5}$ Asma Tabassum ${ }^{5}$, Sumaiya Alam ${ }^{5}$ and Mst Marium Begum ${ }^{6 *}$

\begin{abstract}
Background: Phytochemical derived from plant consisting of phenols and flavonoids possess antioxidant properties, which are useful to scavenge reactive oxygen species (ROS). The aim of the work is to ascertain the level of antioxidant, cytotoxic, anti-microbial properties and in vivo analgesic and anti-inflammatory activity of methanolic extracts of Pouzolzia zeylanica (L.) Benn.

Methods: The present study was conducted to evaluate antioxidant, cytotoxic, anti-microbial potential, analgesic and anti-inflammatory activity of methanol extracts of Pouzolzia zeylanica (L) Benn. using DPPH (1,1-diphenyl-2picrylhydrazyl) scavenging assay, cupric reducing antioxidant capacity, nitric oxide scavenging assay, ferric reducing antioxidant power, total antioxidant capacity, determination of total phenol and flavonoid contents and cytotoxic activity test using brine shrimp lethality bioassay whereas antimicrobial activity was evaluated against some potent Gram positive and Gram negative bacteria by disc diffusion method, anti-inflammatory and analgesic activity were determined by Xylene-induced ear edema and acetic acid induced writhing method respectively.
\end{abstract}

Results: Preliminary phytochemical study revealed the presence of alkaloid and flavonoids in the extract. The tested fraction showed significant antioxidant activities in the assay compared to the reference ascorbic acid in a dose dependent manner. In DPPH radical scavenging assay, the IC50 value of the crude methanol extract was $485.223 \mu \mathrm{g} / \mathrm{mL}$, whereas IC50 value for the reference ascorbic acid was $34.88 \mu \mathrm{g} / \mathrm{mL}$. In case of nitric oxide scavenging assay, the IC50 value of the extract was $76.737 \mu \mathrm{g} / \mathrm{mL}$, whereas IC50 value for the reference ascorbic acid was $51.078 \mu \mathrm{g} / \mathrm{mL}$. Moreover, at $200 \mu \mathrm{g} / \mathrm{mL}$ extract concentration, lower grade total antioxidant activity (160.813 $\pm 0.653 \mathrm{mg} / \mathrm{g}$ equivalent to ascorbic acid) was observed. Furthermore, extract showed good cupric reducing power and ferric reducing power capability. In addition, significant amount of flavonoids and low phenols content were obtained from the extract. In case of cytotoxicity test the crude extract showed a significant activity compared to the standard vincristine sulfate. In essence the tested extract exhibited moderate antibacterial activity which reveals that Pouzolzia zeylanica (L) Benn. might be a source of antimicrobial agent. In case of anti-inflammatory and analgesic activity the tested extracts showed dose dependent significant inhibition (78.86 and $21.95 \%$ at $500 \mathrm{mg} / \mathrm{kg}$ doses).

Conclusions: Further study on different solvent extracts of Pouzolzia zeylanica (L.) Benn. would be carried out to elucidate the active principles for its outmost activity.

Keywords: Pouzolzia zeylanica, Antioxidant, DPPH, Cytotoxicity, Disc diffusion, Antimicrobial activity, Analgesic, Anti-inflammatory

\footnotetext{
*Correspondence: mariumpharm23@gmail.com

${ }^{6}$ Department of Pharmaceutical Technology, Faculty of Pharmacy, University

of Dhaka, Dhaka 1000, Bangladesh

Full list of author information is available at the end of the article
} 


\section{Background}

Free radicals can lead to cell and tissue damage in the body which is reported as oxidative damage [1]. This damage in turn can lead to many degenerative diseases, such as brain dysfunction, cancer, and heart diseases, age-related degenerative conditions, declination of the immune system, cancer, coronary arteriosclerosis, ageing processes, carcinogenesis, gastric ulcer and DNA damage arise [2-7].

Antioxidants have been used for the prevention and treatment of free radical-related disorders [8]. Recent study shows, a number of natural compounds such as polyphenols and flavonoids have been reported as antioxidants, which entrap and deactivate damaging ROS and RNS [9, 10]. Furthermore, they also possess anti-inflammatory, antiviral and anticancer properties [11-13].

Many medicinal plants contain large amounts of antioxidants such as polyphenols, which have an important role in preventing a variety of stress-related diseases and aging which are closely related to the active oxygen and lipid peroxidation [14]. Pouzolzia zeylanica (L.) Benn. (Family: Urticaceae), a perennial herb, height $15-30 \mathrm{~cm}$. It is found all over in Bangladesh. The local name of this plant is Bishkatali, mostly found in Betbunia, Rangamati.

Leaves of this plant are anthelmintic and vulnerary; used as a cicatrizant for gangrenous ulcers, in syphilis and gonorrhea. Leaf juice is used as galactagogue. Poultice of the herb is applied to sores, boils and to relieve stomachache [15]. Moreover, this plant contains flavones, flavonoids, tannin, carotene, carotenoids, ascorbic, tartaric, malic and pectic acids, gum, minerals and their salts [16]. The present research was aimed to investigate the phytochemical constituents, cytotoxic, antibacterial and antioxidant activities of $P$. zeylanica. To evaluate the antioxidant potential of the tested extract of $P$. zeylanica, several assay strategies have been implemented in this study. These consists of various in vitro and in vivo assay systems, such as the DPPH (1,1-diphenyl-2-picrylhydrazyl) scavenging assay, cupric reducing antioxidant capacity, ferric reducing antioxidant power, NO scavenging activity, total antioxidant capacity and determination of total phenol and flavonoid content, analgesic activity and anti-inflammatory activity in order to understand the usefulness of this plant as a functional food as well as in medicine.

\section{Methods}

\section{Chemicals}

DPPH (1, 1-diphenyl, 2-picrylhydrazyl) was purchased from Sigma Chemical Co., USA, potassium fericyanide $\left[\mathrm{K} 3 \mathrm{Fe}(\mathrm{CN})_{6}\right]$ from Loba Chemie Pvt. Ltd., Mumbai, India, Ascorbic acid from SD Fine Chem. Ltd., Biosar, India, Vincristine sulphate from Jayson Pharmaceuticals
Ltd, Bangladesh and neocaproin (C14H12N2), ammonium molybdate, folin-ciocalteun phenol reagent, gallic acid $\left(\mathrm{C}_{7} \mathrm{H}_{6} \mathrm{O}_{5} \cdot \mathrm{H}_{2} \mathrm{O}\right)$, quercetin were purchased from Merck, Germany.

\section{Microorganisms}

The antimicrobial activity assay of the extracts was carried out on both Gram-positive and Gram-negative bacteria.

\begin{tabular}{ll}
\hline Gram positive & Gram negative \\
Bacillus cereus & Escherichia coli \\
Bacillus subtilis & Serratia spp. \\
Staphylococcus aureus & Salmonella typhi \\
& Pseudomonas spp. \\
& Proteus mirabilis \\
\hline
\end{tabular}

These strains were obtained from Department of Microbiology, Jahangirnagar University, Savar, Dhaka, Bangladesh.

\section{Selection of plant}

The plant Pouzolzia zeylanica (L) Benn. was selected for study. The plants were collected from Jahangirnagar University campus, Savar, Dhaka, Bangladesh in August, 2013. The collected plants were identified and authenticated by experts in Bangladesh National Herbarium, Mirpur, Dhaka, where a Voucher specimen has been deposited for future reference.

\section{Methanol extract}

The whole plants were sun dried and then crushed through grinding machine. Then $100 \mathrm{~g}$ of dried whole plant powder were taken in a separate container. To this $250 \mathrm{ml}$ of methanol was added and kept for $24 \mathrm{~h}$ at room temperature with periodic shaking. Then filtered with Whatman No. 1 filter paper and the filtrate was collected. The procedure was repeated three times with fresh volume of methanol. The filtrates were pooled.

\section{Preliminary phytochemical screening}

The freshly prepared crude extract was qualitatively tested for the presence of chemical constituents. Phytochemical screenings of the extracts were performed using the following reagents and chemicals: alkaloids with Dragendorff's reagents, flavonoids with the use of $\mathrm{Mg}$ and $\mathrm{HCl}$; tannins with ferric chloride and potassium dichromate solutions and saponins with ability to produce stable foam and steroids with Libermann- Burchard reagent. Gum was tested using Molish reagent and concentrated sulfuric acid; reducing sugars with Benedict's reagent. These were 
identified by characteristic color changes using standard procedures by Ghani A., 2005 [17].

\section{Tests for antioxidant activity}

\section{DPPH free radical scavenging activity}

The free radical scavenging activity of the extracts, based on the scavenging activity of the stable 1, 1-diphenyl-2picrylhydrazyl (DPPH) free radical, were determined by the method described by Bracaet al., 2001 [18]. The method is based on the reduction of ethanolic $\mathrm{DPPH}^{-}$ solution in the presence of a hydrogen donating antioxidant, due to the formation of the non-radical form DPPH-H by reaction. Plant extract $(0.1 \mathrm{~mL})$ of each concentrations were added to $3 \mathrm{~mL}$ of a $0.004 \%$ ethanol solution of DPPH. Absorbance at $517 \mathrm{~nm}$ was determined after $30 \mathrm{~min}$ and the percentage inhibition activity was calculated from $[(\mathrm{Ao}-\mathrm{A} 1) / \mathrm{Ao}] \times 100$, where Ao is the absorbance of the control (DPPH solution) and A1 is the absorbance of the extract/standard. The inhibition curves were prepared and IC50 values were calculated.

\section{Ferric reducing antioxidant power (FRAP)}

The ferric reducing antioxidant power was determined according to the method previously described by Oyaizu, 1986 [19]. According to this method, the reduction of $\mathrm{Fe} 3+$ to $\mathrm{Fe} 2+$ is determined by measuring the absorbance of Perl's Prussian blue complex. Briefly, different concentrations of extracts $(5-200 \mu \mathrm{g})$ in $1 \mathrm{~mL}$ of distilled water were mixed with phosphate buffer $(2.5 \mathrm{~mL}, 0.2 \mathrm{M}$, $\mathrm{pH}$ 6.6) and potassium ferricyanide [K3Fe(CN)6] $(2.5 \mathrm{~mL}, 1 \%)$. The mixture was incubated at $50{ }^{\circ} \mathrm{C}$ for $20 \mathrm{~min}$. An aliquot $(2.5 \mathrm{~mL})$ of trichloroacetic acid (10\%) was added to the mixture, which was then centrifuged at $3000 \mathrm{rpm}$ for $10 \mathrm{~min}$. The supernatant $(2.5 \mathrm{~mL})$ was mixed with distilled water $(2.5 \mathrm{~mL})$ and $\mathrm{FeCl} 3$ $(0.5 \mathrm{~mL}, 0.1 \%)$ and the absorbance was measured at $700 \mathrm{~nm}$. Increased absorbance of the reaction mixture indicated increased reducing power. Ascorbic acid was used as the reference.

\section{Cupric reducing antioxidant capacity}

The cupric reducing antioxidant activity of the methanol extract was determined by the method described by Resatet al., 2004 [20]. Different concentrations of the extract $(5-200 \mu \mathrm{g})$ in $0.5 \mathrm{~mL}$ of distilled water were mixed with Cupric Chloride $(1 \mathrm{~mL}, 0.01 \mathrm{M})$, Ammonium acetate buffer ( $1 \mathrm{~mL}, \mathrm{pH} 7.0)$, Neocaproin $(1 \mathrm{~mL}, 0.0075 \mathrm{M})$ and finally distilled water $(0.6 \mathrm{~mL})$. The mixture was incubated for $1 \mathrm{~h}$ at room temperature. Then the absorbance of the solution was measured at $450 \mathrm{~nm}$ against blank. Distilled water $(0.5 \mathrm{~mL})$ in the place of extract is used as the blank. The molar absorptivity of the Cuprac method for each antioxidant was found from the slope of the calibration line concerned. Ascorbic acid was used as the standard solution.

\section{Nitric oxide scavenging assay}

Based on the principle that the compound Sodium Nitroprusside (SNP) is known to decompose in aqueous solution at physiological $\mathrm{pH}$ (7.2) producing NO. Under aerobic conditions, NO. reacts with oxygen to produce stable products: nitrate and nitrite, the quantities of nitrate and nitrite can be determined using Griess reagent. The scavenging effect of $P$. zeylanica extract on nitric oxide was measured according to the method of Alisi and Onyeze, 2008 [21]. Briefly $4 \mathrm{ml}$ of extracts solution at different concentrations were added (in the test tubes) to $1 \mathrm{ml}$ of Sodium Nitroprusside (SNP) solution $(25 \mathrm{mM})$ and the tubes incubated at $29{ }^{\circ} \mathrm{C}$ for $2 \mathrm{~h}$. A $2 \mathrm{ml}$ aliquot of the incubation solution was diluted with $1.2 \mathrm{ml}$ Griess Reagent ( $1 \%$ sulfanilamide in $5 \% \mathrm{H}_{3} \mathrm{PO}_{4}$ and $0.1 \%$ naphthylethylenediamine-dihydrochloride). The absorbance of the chromophore that formed during diazotization of the nitrite with sulfanilamide and subsequent coupling with naphthylethylenediamine dihydrochloride was immediately read at $550 \mathrm{~nm}$. The percentage (\%) inhibition activity was calculated from the following equation $\left\{\left(\mathrm{A}_{0}-\mathrm{A}_{1}\right) / \mathrm{A}_{0}\right\} \times 100$. Where, $\mathrm{A}_{0}$ is the absorbance of the Control and $A_{1}$ is the absorbance of the extract or standard. $\mathrm{IC}_{50}$ was calculated by linear regression method.

\section{Determination of total antioxidant capacity}

The antioxidant activity of the extract was evaluated by the phosphomolybdenum method according to the procedure describe by Prietoet al, 1999 [22]. A $0.3 \mathrm{~mL}$ extract was combined with $3 \mathrm{~mL}$ of reagent solution (0.6 M sulfuric acid, $28 \mathrm{mM}$ sodium phosphate and $4 \mathrm{mM}$ ammonium molybdate). The tubes containing the reaction solution were incubated at $95{ }^{\circ} \mathrm{C}$ for $90 \mathrm{~min}$. Then the absorbance of the solution was measured at $695 \mathrm{~nm}$ using a spectrophotometer (UV visible spectrophotometer, Shimadzu, 1601) against blank after cooling at room temperature. Methanol $(0.3 \mathrm{~mL})$ in the place of extract is used as the blank. The antioxidant activity is expressed as the number of equivalents of ascorbic acid.

\section{Determination of total phenol content}

The total phenolic content of plant extract was determined using Folin-Ciocalteu reagent [23]. Plant extract $(100 \mu \mathrm{L})$ was mixed with $500 \mu \mathrm{L}$ of the Folin-Ciocalteu reagent and $1.5 \mathrm{~mL}$ of $20 \%$ sodium carbonate. The mixture was shaken thoroughly and made up to $10 \mathrm{~mL}$ using distilled water. The mixture was allowed to stand for $2 \mathrm{~h}$. Then the absorbance at $765 \mathrm{~nm}$ was determined. These data were used to estimate the phenolic contents 
using a standard curve obtained from various concentration of Gallic acid.

\section{Determination of total flavonoid content}

The content of flavonoids compounds in the extract was determined by the method described by Chang et al., 2002 [24]. One milliliter of extract was mixed with methanol $(3 \mathrm{~mL})$, aluminium chloride $(0.2 \mathrm{~mL}, 10 \%)$, potassium acetate $(0.2 \mathrm{~mL}, 1 \mathrm{M})$ and distilled water $(5.6 \mathrm{~mL})$ and incubated the mixture for $30 \mathrm{~min}$ at room temperature. Then the absorbance was measured at $415 \mathrm{~nm}$ against blank. Methanol $(1 \mathrm{~mL})$ in the place of extract was used as the blank and Quercetin was used as the standard solution. All determinations were carried out in triplicates. The amount of flavonoids in plant extracts in quercetin equivalents $(\mathrm{QE})$ was calculated by the following formula: $\mathrm{X}=\left(\mathrm{A} \times \mathrm{m}_{0}\right) /\left(\mathrm{A}_{0} \times \mathrm{m}\right)$, where $\mathrm{X}$ is the flavonoid content, $\mathrm{mg} / \mathrm{mg}$ plant extract in $\mathrm{QE}, \mathrm{A}$ is the absorption of plant extract solution, $\mathrm{A}_{0}$ is the absorption of standard rutin solution, $\mathrm{m}$ is the weight of plant extract in $\mathrm{mg}$ and $\mathrm{m}_{0}$ is the weight of quercetin in the solution in $\mathrm{mg}$.

\section{Cytotoxicity test}

Brine shrimp lethality bioassay was used for probable cytotoxic action [25, 26]. The eggs of brine shrimp (Artemia salina Leach) were collected and hatched in a tank at a temperature around $37{ }^{\circ} \mathrm{C}$ with constant oxygen supply. Two days were allowed to hatch and mature the nauplii. Stock solution of the extract sample was prepared by dissolving required amount of extract in specific volume of pure dimethyl sulfoxide (DMSO). 10 living nauplii were taken to each of the vial containing different concentrations of test sample with Pasteur pipette. Then specific volumes of sample were transferred from the stock solution to the vials to get final sample concentration. In the control vials same volumes of DMSO (as in the sample vials) were taken. Vincristine sulphate was used as the positive control. After $24 \mathrm{~h}$ the vials were observed and the number of nauplii survived in each vial was counted. From this, the percentage of mortality of brine shrimp nauplii was calculated for each concentration of the extract.

\section{Antibacterial activity by disc diffusion method}

The antibacterial activity of the plant extract was performed by the well accepted Bauer-Kirby disc diffusion method [27, 28]. The inoculums of microorganisms were spread over nutrient agar plates with a sterile swab. One hundred milligram of the test sample was dissolved in $1 \mathrm{ml}$ of methanol to obtain the concentration $100 \mu \mathrm{g} / \mu \mathrm{l}$ in an aseptic condition. Sterilized metrical filter paper discs (Whatman No. 1, $6 \mathrm{~mm}$ diam.) were soaked with 30, 20 and $10 \mu \mathrm{l}$ of solutions of test sample. Then the discs were placed on the previously marked agar plate and dried. The extract was tested in triplicate and the plates were inoculated at $37{ }^{\circ} \mathrm{C}$ for $24 \mathrm{~h}$. Antibacterial activities were evaluated by measuring inhibition zone diameters. Amoxicillin was used as positive control.

\section{In-vivo pharmacological activity evaluation Acute toxicity study}

Overnight-fasted Swiss albino mice (39-45 g) of either sex were used for the study. The animals were divided into seven groups of five animals each. Groups A to F received orally $250,500,1000,2000,3000,4000 \mathrm{mg} / \mathrm{kg}$ of the extract, respectively, while the control (group G), received distilled water $(3 \mathrm{~mL} / \mathrm{kg})$ by the same route. General symptoms of toxicity and mortality in each group were observed within $24 \mathrm{~h}$. Animals that survived after $24 \mathrm{~h}$ were observed for any signs of delayed toxicity for 2 weeks.

\section{Anti-inflammatory activity evaluation Xylene induced ear edema}

Swiss albino mice were divided into four groups of five animals each. Animals were treated orally with the extract $(250$ and $500 \mathrm{mg} / \mathrm{kg})$, diclofenac $(1 \mathrm{mg} / \mathrm{kg})$ and distilled water $(3 \mathrm{~mL} / \mathrm{kg})$. Thirty minutes later, edema was induced in each mouse group by applying a drop of xylene to the inner surface of the right ear. After $15 \mathrm{~min}$, the animals were sacrificed under ether anesthesia and both ears cut off, sized and weighed. The anti-inflammatory activity was expressed as the percent-age inhibition of edema in the treated mice in comparison with the control mice [29].

\section{Analgesic activity evaluation \\ Acetic acid induced writhing \\ The method according to (Koster et al, 1959) [30] was employed for this test. Four groups of five mice each were pretreated with extracts (250 and $500 \mathrm{mg} / \mathrm{kg}$ ),}

Table 1 Results of phytochemical screening of methanol extract of Pouzolzia zeylanica (L.) Benn

\begin{tabular}{|c|c|c|c|c|c|c|c|c|c|c|}
\hline Extract & Alkaloid & test & & Carbohydrate test & Flavonoid test & Glucoside test & Glycoside test & Saponin test & Steroid test & Tanin test \\
\hline \multirow[t]{3}{*}{ PZME } & Hagers & Wagners & Dragendorffs & + & + & - & + & - & + & + \\
\hline & Test & Test & Test & & & & & & & \\
\hline & + & + & + & & & & & & & \\
\hline
\end{tabular}

PZME Pouzolzia zeylanica (L.) Benn. Methanol, Values are the average of triplicate experiments and represented as mean \pm SD; (+): Present; (-): Absent 


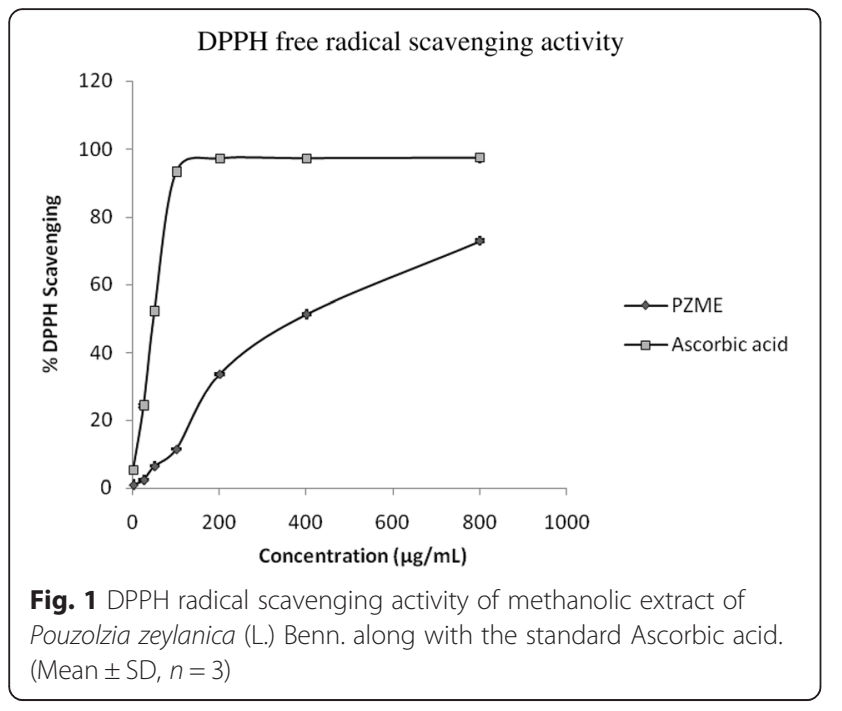

diclofenac $(1 \mathrm{mg} / \mathrm{kg})$ and distilled water $(3 \mathrm{~mL} / \mathrm{kg})$. Forty five minutes later each mouse was injected intraperitoneally with $0.7 \%$ acetic acid at a dose of $10 \mathrm{ml} / \mathrm{kg}$ body weight. The number of writhing responses was recorded for each animal during a subsequent 5 min period after 15 min i.p. administration of acetic acid and the mean abdominal writhing for each group was obtained. The percentage inhibition of writhing was calculated by comparison with the control mice.

\section{Statistical analysis}

The results were expressed as mean \pm standard deviation (SD) from triplicate experiments and evaluated with the analysis of student's $t$-test. Differences were considered significant at a level of $P<0.05$. IC50 was calculated using Sigma Plot 11.0 software.

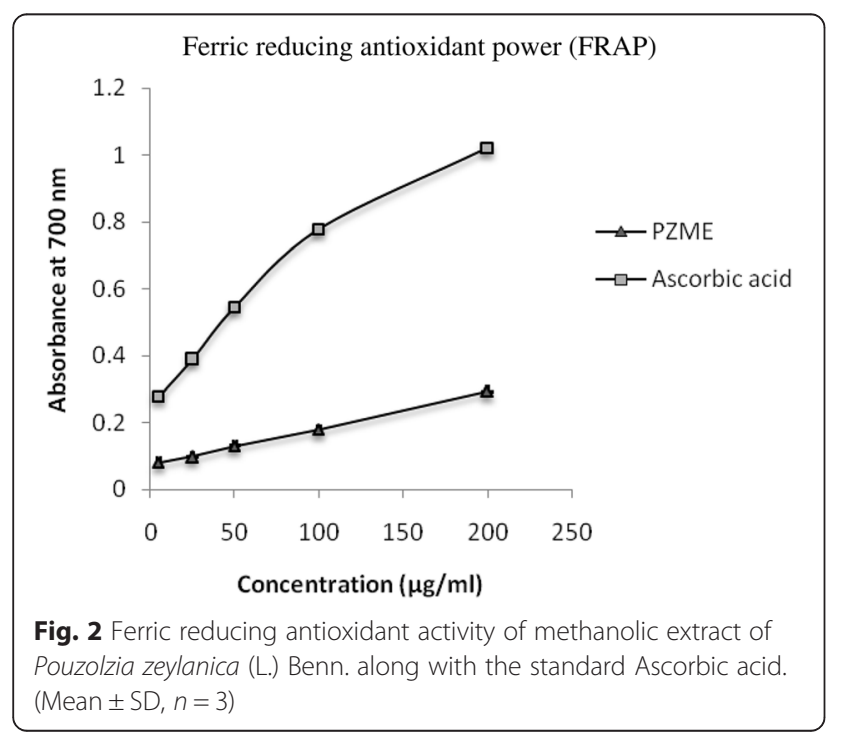

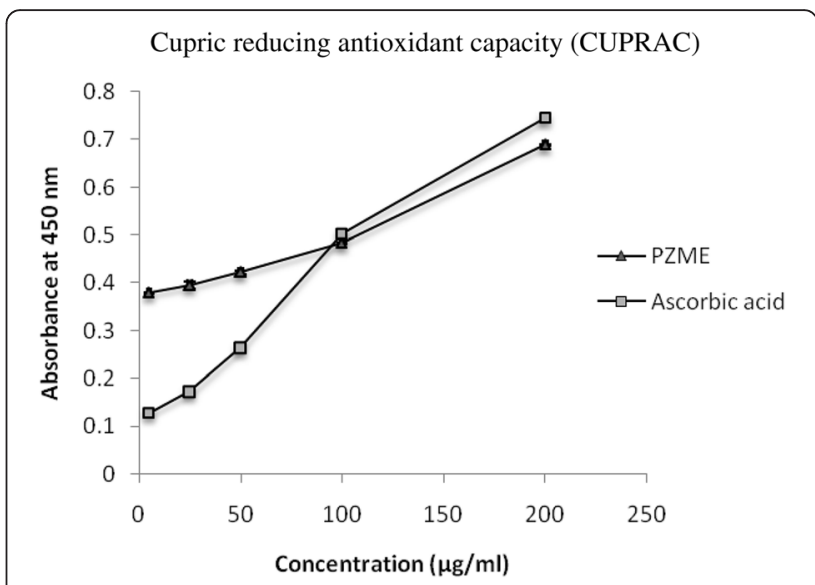

Fig. 3 CUPRAC reducing antioxidant activity of methanolic extract of Pouzolzia zeylanica (L.) Benn. along with the standard Ascorbic acid. (Mean $\pm \mathrm{SD}, n=3$ )

\section{Results and discussion}

Preliminary qualitative phytochemical screening

The methanolic extract of P. zeylanica (L) Benn. has been shown to possess phytoconstituents including carbohydrates, alkaloids, glycosides, steroids, tannins, flavonoids and saponin etc. (Table 1). These phytoconstituents present in the extracts may account for their various pharmacological activities shown in other investigations [17].

\section{$\mathrm{DPPH}^{-}$radical scavenging activity}

In DPPH radical scavenging assay, as shown in Fig. 1, here the extract exhibited a concentration dependent antiradical activity by inhibiting $\mathrm{DPPH}^{-}$radical. Ascorbic acid, which is a well-known antioxidant, showed higher degree of free radical-scavenging activity than that of the plant extract at each concentration points. The IC50 value of the methanol extract was $485.223 \mu \mathrm{g} / \mathrm{mL}$, while the IC50 value for the reference ascorbic acid was $34.88 \mu \mathrm{g} / \mathrm{mL}$. The extracts were able to reduce DPPH

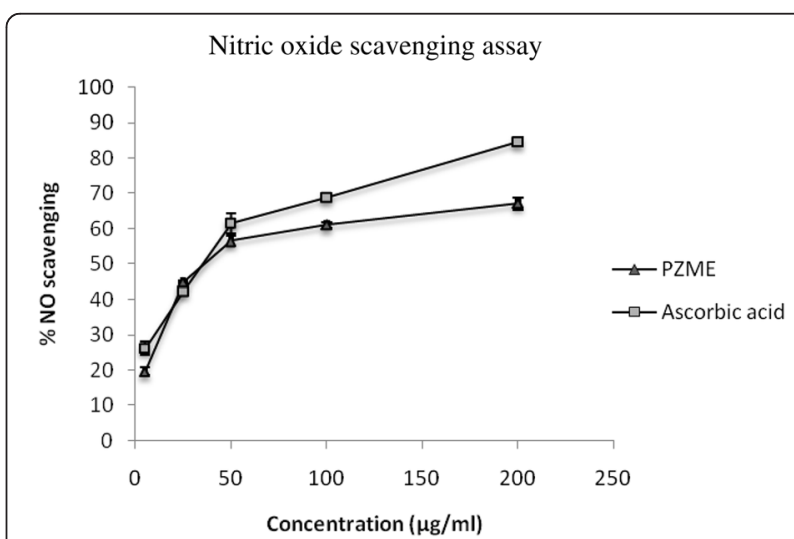

Fig. 4 Nitric Oxide (NO) scavenging activity of methanolic extract of Pouzolzia zeylanica (L.) Benn. along with the standard Ascorbic acid. (Mean $\pm S D, n=3$ ) 
Table 2 Total antioxidant capacity, total phenol and total flavonoid contents of methanol extracts of the bark and leaf of Pouzolzia zeylanica (L.) Benn

\begin{tabular}{lccc}
\hline Extract & $\begin{array}{l}\text { Total antioxidant } \\
\text { capacity equivalent } \\
\text { to ascorbic acid } \\
\mathrm{mg} / \mathrm{g} \text { plant extract }\end{array}$ & $\begin{array}{l}\text { Total phenol } \\
\text { (in } \mathrm{mg} / \mathrm{g}, \text { gallic } \\
\text { acid equivalents) }\end{array}$ & $\begin{array}{l}\text { Total flavonoid } \\
\text { (in } \mathrm{mg} / \mathrm{g} \text {, quercetin } \\
\text { equivalents) }\end{array}$ \\
\hline PZME & $160.813 \pm 0.653$ & $82.428 \pm 1.02$ & $89.235 \pm 1.082$ \\
\hline
\end{tabular}

PZME Pouzolzia zeylanica (L.) Benn. Methanol, Values are the average of triplicate experiments and represented as mean \pm SD

radical (visible deep purple color) to the yellow-coloured diphenylpicrylhydrazine. It has been found that cysteine, glutathione, ascorbic acid, tocopherol, polyhydroxy aromatic compounds (e.g. hydroquinone, pyrogallol, gallic acid), and aromatic amines (e.g. p-phenylenediamine, paminophenol), reduce and decolorise 1,1-diphenyl-2picrylhydrazyl by their hydrogen donating ability [31]. This is concluded that the plant might have active principles that can be used as antioxidants.

\section{Ferric reducing antioxidant power (FRAP)}

Figure 2 shows the reducing power capabilities of the plant extract compared to ascorbic acid. The extract displayed moderate reducing power which was found to rise with increasing concentrations of the extract. In reducing power assays, the presence of antioxidants in the root can reduce the oxidized form of iron $(\mathrm{Fe} 3+)$ to its reduced form $(\mathrm{Fe} 2+)$ by donating an electron. Thus, it can be assumed that the presence of reductants (i.e. antioxidants) in P. zeylanica (L) Benn. extract causes the reduction of the $\mathrm{Fe} 3+/$ ferricyanide complex to the ferrous form which reveals the antioxidative nature of the extract. Therefore, the Fe2+ complex can be monitored by measuring the formation of Perl's Prussian blue at $700 \mathrm{~nm}$. A higher absorbance indicates greater reducing power ability [32].

\section{Cupric reducing antioxidant capacity (CUPRAC)}

The reducing ability of a compound generally depends on the presence of reductants [33], which have been reported to exhibit antioxidative potential by breaking the free radical chain, donating a hydrogen atom [32].

According to changed concentration trend, we concluded that the reducing power of the extract was lower than that of ascorbic acid but it was significant (Fig. 3). The probable mechanism of Cupric reducing power of extracts, would be the resultant of having a good number of polyphenolics and flavonoids, as the reactive hydroxyl groups of polyphenolics, oligomeric flavonoids, is oxidized with the CUPRAC reagent to the corresponding quinines [20].

\section{Nitric oxide scavenging assay}

Nitric Oxide (NO) scavenging assay is based on the scavenging ability of the extracts as well as ascorbic acid, which is used as standard. The scavenging of the NO generated from sodium nitroprusside in vitro indicates the possibility of preventing the peroxynitrite formation in the cell in vivo [34]. Reducing the nitric oxide generation in the digestive tract was reported to be effective in preventing the reactions of nitrate with amines and amides to form carcinogenic nitrosamines and nitrosamides [35, 36]. The scavenging of NO was found to increase in dose dependent manner (Fig. 4). The IC50 value of the crude extract was $76.737 \mu \mathrm{g} / \mathrm{mL}$, while the IC50 value for the

Table 3 \% Mortality of Brine shrimp produced by Pouzolzia zeylanica (L.) Benn. and the standard Vincristine sulphate

\begin{tabular}{|c|c|c|c|c|c|c|}
\hline Test sample & Concentration $(\mu \mathrm{g} / \mathrm{ml})$ & Log concentration & $\%$ Mortality & Corrected \% mortality & $\mathrm{LC}_{50}(\mu \mathrm{g} / \mathrm{ml})$ & $\mathrm{LC}_{90}(\mu \mathrm{g} / \mathrm{ml})$ \\
\hline \multirow[t]{7}{*}{ PZME } & 12.5 & 1.09691 & 40 & 33.33 & 46.24 & 363.07 \\
\hline & 25 & 1.39794 & 40 & 33.33 & & \\
\hline & 50 & 1.69897 & 50 & 44.44 & & \\
\hline & 100 & 2 & 60 & 55.55 & & \\
\hline & 200 & 2.30103 & 80 & 77.55 & & \\
\hline & 400 & 2.60206 & 100 & 100 & & \\
\hline & 800 & 2.90309 & 100 & 100 & & \\
\hline \multirow[t]{7}{*}{ VS } & 0.06 & -1.22185 & 10 & 0 & 0.0699 & 6.33 \\
\hline & 0.125 & -0.90309 & 20 & 11.11 & & \\
\hline & 0.25 & -0.60206 & 30 & 22.22 & & \\
\hline & 0.5 & -0.30103 & 40 & 33.33 & & \\
\hline & 1 & 0 & 50 & 44.44 & & \\
\hline & 5 & 0.69897 & 90 & 88.88 & & \\
\hline & 10 & 1 & 100 & 100 & & \\
\hline
\end{tabular}


reference ascorbic acid was $51.078 \mu \mathrm{g} / \mathrm{mL}$. Based on these we speculate that nitric oxide scavenging activity of Pouzolzia zeylanica (L) Benn. may have great relevance in the prevention and control of disorders where $\mathrm{NO}$ is thought to play a key role.

\section{Determination of total antioxidant capacity}

The total antioxidant capacity of the methanol extract of P.zeylanica (L) Benn. is given in Table 2. Significant amount of total antioxidant activity was obtained from the methanol extract $(160.813 \pm 0.653 \mathrm{mg} / \mathrm{g}$ ascorbic acid equivalent) at $200 \mu \mathrm{g} / \mathrm{mL}$ extract concentration. The phosphomolybdenum method was based on the reduction of $\mathrm{Mo}(\mathrm{VI})$ to $\mathrm{Mo}(\mathrm{V})$ by the antioxidant compound and the formation of a green phosphate/Mo(V) complex with a maximal absorption at $695 \mathrm{~nm}$. The assay is successfully used to quantify vitamin $\mathrm{E}$ in seeds and, being simple and independent of other antioxidant measurements commonly employed, it was decided to extend its application to plant extracts [22]. Moreover, it is a quantitative one, since the antioxidant activity is expressed as the number of equivalents of ascorbic acid.

\section{Determination of total phenol content}

It has been conclusively shown close relationship between total phenolic content and antioxidative activity of the fruits and vegetables based on several reports. Phenolic compounds, as natural antioxidants exhibit therapeutic potential in multiple diseases including cardiovascular disease, aging and cancer [33]. It has been reported that phenolic compounds with orthoand para-dihydroxylation or a hydroxyl and a methoxy group are more effective than simple phenolics [37]. Moreover, the antioxidant activity of phenolic compounds is mainly due to their redox properties, which can play an important role in adsorbing and neutralizing free radicals, quenching singlet and triplet oxygen, or decomposing peroxides [33]. However, the methanol extract of the P. zeylanica (L) Benn. was found to contain little amount of phenolics $82.428 \pm 1.02 \mathrm{mg} / \mathrm{g}$ Gallic acid equivalent (GAE) using Folin-Ciocalteau method. The result was presented in Table 2.

\section{Determination of total flavonoids content}

It has been reported that flavonoids play an important role in antioxidant system in plants. The antioxidative properties of flavonoids are due to several different mechanisms, such as scavenging of free radicals, chelation of metal ions, such as iron and copper, and inhibition of enzymes responsible for free radical generation [38]. However, total flavonoid content of P. zeylanica (L) Benn. extract is shown in Table 2. The result was
Table 4 Zone of Inhibition produced by Methanolic Extract of Pouzolzia zeylanica (L.) Benn. against some Gram positive and Gram negative bacteria

\begin{tabular}{|c|c|c|c|c|}
\hline \multirow[t]{3}{*}{ Test microorganism } & \multicolumn{4}{|c|}{ Zone of inhibition in $\mathrm{mm}$} \\
\hline & \multicolumn{3}{|c|}{$\begin{array}{l}\text { Extract Conc. } \mu \mathrm{l} / \mathrm{disc} \\
\text { Pouzolzia zeylanica (L.) Benn. }\end{array}$} & \multirow{2}{*}{$\begin{array}{l}\text { Standard amoxicillin } \\
10\end{array}$} \\
\hline & 10 & 20 & 30 & \\
\hline Bacillus subtilis & 7.5 & 7.5 & 8.0 & 28.5 \\
\hline Bacillus cereus & 7.0 & 7.5 & 8.5 & 9.5 \\
\hline S.aureus & 8.5 & 8.5 & 9.5 & 12.5 \\
\hline P.mirrabilis & 7.5 & 8.0 & 9.0 & 9.5 \\
\hline E.coli & 7.0 & 7.0 & 8.5 & 18.0 \\
\hline Serratia spp. & 8.0 & 8.5 & 10.0 & 10.5 \\
\hline S.typhi & 7.5 & 8.0 & 8.5 & 12.0 \\
\hline Pseudomonas spp. & 7.0 & 7.0 & 8.0 & 20.5 \\
\hline
\end{tabular}

exhibited as quercetin equivalent of flavonoids per gm of extracts of the sample. For the claimed extract, the total flavonoid content was found to be $89.235 \pm 1.082 \mathrm{mg} / \mathrm{g}$ Quercetin equivalent. These results suggested that flavonoid contents might be responsible for the antioxidant activities of P. zeylanica (L) Benn.

\section{Cytotoxic activity test}

The cytotoxicity of the crude extracts to brine shrimp was determined on Artemia salina [26]. Table 3 shows the results of the brine shrimp lethality testing after $24 \mathrm{~h}$ of exposure to the samples and the positive control, vincristine sulphate. The LC50obtained from the semi log plot were found 0.0699 and $46.24 \mu \mathrm{g} / \mathrm{mL}$ for vincristine sulphate (positive control) and DMSO soluble fraction of methanolic crude extract, respectively whereas the LC90 for vincristine sulphate and the tested extract was 363.07 and $6.33 \mu \mathrm{g} / \mathrm{mL}$. The results of this study indicate that there might be presence of potent bioactive principles in this crude extract which might be very useful as antitumor, pesticidal and other cytotoxic use.

Table 5 Effect of methanolic extract of Pouzolzia zeylanica (L.) Benn. in Xyline Induced Ear Edema Test

\begin{tabular}{llcl}
\hline Group & Doses $(\mathrm{mg} / \mathrm{kg})$ & $\begin{array}{l}\text { Ear Wt } \\
\text { difference }(\mathrm{mg})\end{array}$ & \% inhibition \\
\hline Control & $\begin{array}{l}1 \% \text { Tween } 80 \text { in } \\
\text { Water }(10 \mathrm{ml} / \mathrm{kg})\end{array}$ & $1.23 \pm 0.015$ & --------- \\
Diclofenac & 100 & $9.5 \pm 0.213$ & 82.02 \\
PZME & 250 & $11.83 \pm 0.143$ & 76.34 \\
PZME & 500 & $11.17 \pm 0.032^{*}$ & 78.86 \\
\hline
\end{tabular}

Values of ear weight are mean \pm S.E.M, $(n=5),{ }^{*} P<0.05$, significantly different from control; done by independent sample $t$-test, (PZME $=$ Pouzolzia zeylanica (L.) Benn. Methanol) 


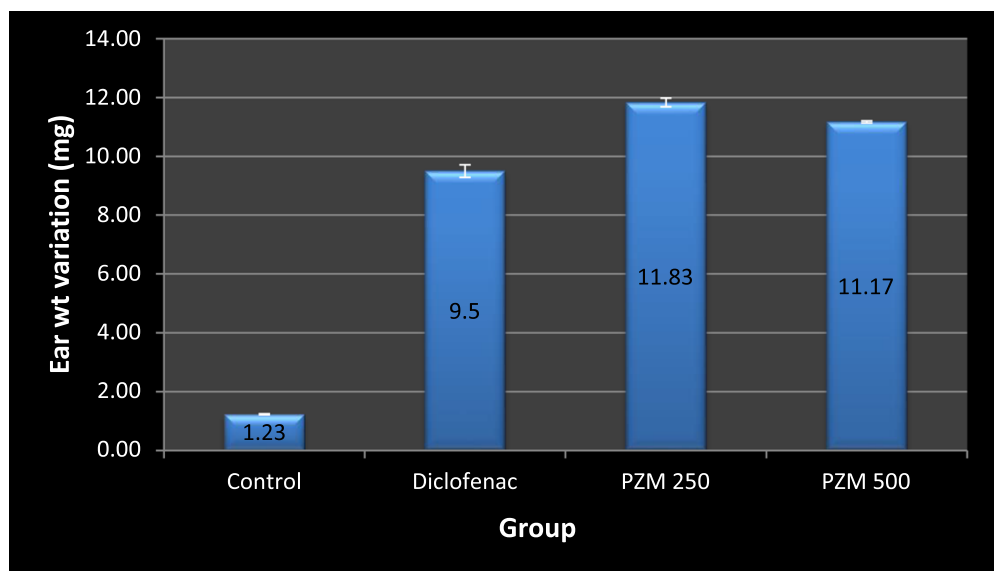

Fig. 5 Variation of ear weight of different groups in Xyline Induced Ear Edema test

\section{Antimicrobial activity}

Plants are important source of potentially useful sources for the development of new chemotherapeutic agents. The first step towards this goal is the in vitro antibacterial activity assay [39]. Table 4 reveals the antibacterial activity of the extract. Significant zone of inhibition was observed against all the studied pathogens by methanol extracts of Pouzolzia zeylanica (L) Benn. Which concludes that tested fraction might have active compounds that can be a source of potential antimicrobial agent though further study is require.

\section{Acute toxicity study}

After the acute toxicity studies no mortality was observed up to dose as high as $4000 \mathrm{mg} / \mathrm{kg}$ for the extract. So no $\mathrm{LC}_{50}$ could be obtained and extracts were considered to be safer with broad therapeutic range. Therefore, two comparative doses (250 and $500 \mathrm{mg} / \mathrm{kg}$ ) for the extract was taken for the in-vivo models.

\section{The Xylene induced ear edema method}

The xylene ear edema model is a useful method that can be utilized to evaluate the anti-inflammatory steroids and is less sensitive to non-steroidal anti-inflammatory agents [40]. Histopathologically, severe vasodilation, edematous changes of skin and infiltration of inflammatory cells are detected as signs of acute inflammation after topical application of xylene [41].

The increase in weight and inflammation exerted by xylene application is due to neutrophil accumulation which plays a critical role in cutaneous inflammatory diseases such as dermatitis, and is related to the pathological mechanism of the disease [42]. In the present study the extracts reduced the ear edema in dose dependent manner (Table 5). The extract at higher dose $(500 \mathrm{mg} / \mathrm{kg})$ showed marked $(p<0.05)$ inhibition whereas at low dose extract it was promising $(76.34 \%)$. Figure 5 showed the variation of ear weight of different groups in Xyline Induced Ear Edema test in a graphical manner.

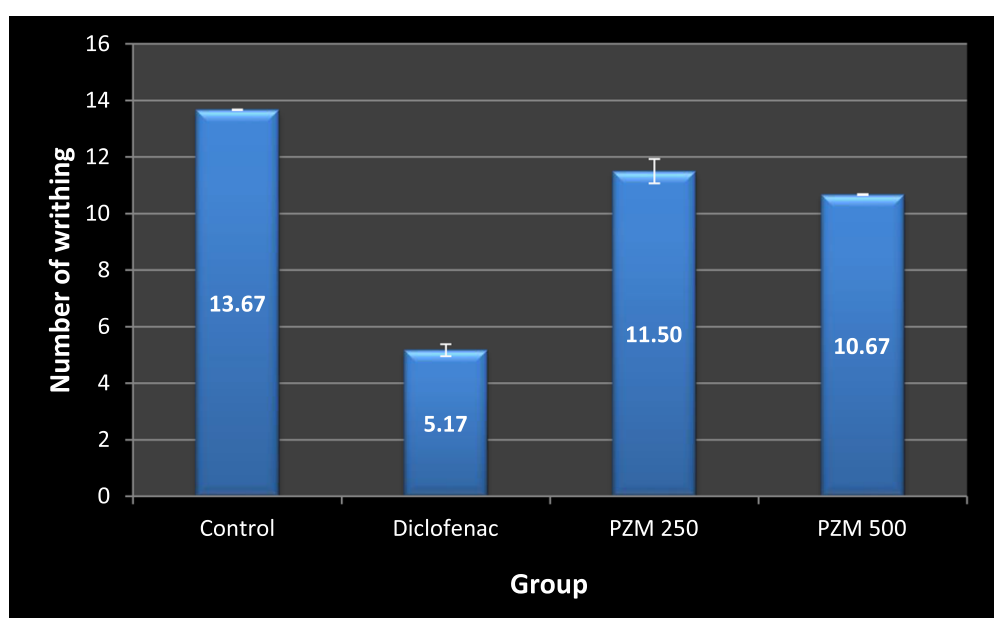

Fig. 6 Number of writhing observed in different groups in Acetic Acid Writhing test 
Table 6 Effect of methanolic extract of Pouzolzia zeylanica (L.) Benn. In Acetic Acid Induced Writhing test

\begin{tabular}{llll}
\hline Group & Doses $(\mathrm{mg} / \mathrm{kg})$ & Number of writhing & \% Inhibition \\
\hline Control & $1 \%$ Tween 80 in & $13.67+0.012$ & --------- \\
& Water $(10 \mathrm{ml} / \mathrm{kg})$ & & \\
Diclofenac & 100 & $5.17+0.213^{*}$ & 62.20 \\
PZME & 250 & $11.5+0.432$ & 15.85 \\
PZME & 500 & $10.67+.013$ & 21.95 \\
\hline
\end{tabular}

Number of writhing values are mean \pm S.E.M. $(n=5),{ }^{*} P<0.05$ significantly different from control; done by independent $t$-test, PZME = Pouzolzia zeylanica (L.) Benn. Methanol

\section{Acetic acid induced writhing method}

Acetic acid induced writhing model represents pain sensation by triggering localized inflammatory response. Such pain stimulus leads to the release of free arachidonic acid from tissue phospholipids [43]. The acetic acid induced writhing response is a sensitive procedure to evaluate peripherally acting analgesics. The response is thought to be mediated by peritoneal mast cells [44] acid sensing ion channels [45] and the prostaglandin.

Figure 6 showed the number of writhing observed in different groups in Acetic Acid Writhing test while Table 6 represents the effect of the extract of in Acetic Acid Induced Writhing test. The methanol extract inhibited writhes in a dose dependent manner (15.85 and $21.95 \%$ respectively) while the standard Diclofenac showed a significant inhibition (62.20\%).

\section{Conclusions}

The current study clearly indicates that the methanolic extract contains significant amount of antioxidants. This might be rationale behind the using of this plant extract as folk medicine. Since the chemical composition and structures of active extract components are important factors governing the efficacy of natural antioxidants, the extracts of P. zeylanica (L.) Benn. need their characterization and quantification of the bioactive components. Therefore, further research is necessary for elucidating the active principles e.g. alkaloids and phenolics compound and also in- vivo studies are needed for understanding their mechanism of action as an antioxidant. Furthermore in vitro and in vivo studies are to be conducted to elucidate the potentiality of the extract as medicine as it shows significant activity against the studied organisms. Whereas more in vivo studies are necessary to examine the underlying mechanism of antiinflammatory and analgesic effects.

\section{Competing interests}

Md. Solayman Hossain, M. Sohanur Rahman, A.H.M. Rahmatullah Imon, Sinthia Zaman, A.S.M. Badrul Alam Siddiky, Milon Mondal, Abeer Sarwar, Tamanna Binte Huq, Bikash Chandra Adhikary, Taslima Begum, Asma Tabassum, Sumaiya Alam, Mst. Marium Begum declare that they have no competing interest.

\section{Authors' contributions}

MSH, SZ, ASMBAS, MM performed all of the experiments in the laboratory. Data collection, analysis, graphical representation and interpretation were done by AHMRI and MSR. Article was written by AS and TBH. Critical revision of the article was done by BCA, TB, AS and SA. Critical statistical analysis was done by AHMRI. MSR made the necessary corrections in the write up. Conception, experiment design, overall monitoring and final approval of the article was done by MMB. It was a self funded research initiavtives. All authors take full responsibility for the content of the paper. All Authors read and approved the final manuscripts.

\section{Acknowledgement}

The authors are thankful to Department of Microbiology, Jahangirnagar University for their support.

\section{Author details}

1Department of Pharmacy, Jahangirnagar University, Savar, Dhaka 1342, Bangladesh. ${ }^{2}$ Department of Biochemistry and Molecular Biology, University of Rajshahi, Rajshahi 6205, Bangladesh. ${ }^{3}$ Ball State University, Muncie, IN 47306, USA. ${ }^{4}$ Department of Pharmaceutical Sciences, North South University, Dhaka 1229, Bangladesh. ${ }^{5}$ Department of Pharmacy, Primeasia University, Banani, Dhaka 1213, Bangladesh. ${ }^{6}$ Department of Pharmaceutical Technology, Faculty of Pharmacy, University of Dhaka, Dhaka 1000, Bangladesh.

Received: 2 February 2016 Accepted: 1 April 2016

Published online: 26 April 2016

\section{References}

1. Halliwell B, Gutteridge JMC. Free radical in biology and medicine. Oxford: Clerendon; 1989.

2. Grzegorczyk I, Matkowski A, Wysokińska H. Antioxidant activity of extracts from in vitro cultures of Salvia officinalis L. Food Chem. 2007;104(2):536-41.

3. Kumaran A, Karunakaran RJ. In vitro antioxidant activities of methanol extracts of five Phyllanthus species from India. LWT Food Sci Technol. 2007;40(2):344-52

4. Shen Q, Zhang B, Xu R, Wang Y, Ding X, Li P. Antioxidant activity in vitro of the selenium contained protein from the Se-enriched Bifidobacterium animal is. Anaerobe. 2010;16(4):380-6.

5. Slater TF. Free-radical mechanisms in tissue injury. Biochemical J. 1984;222:1-15.

6. Prakash D, Upadhyay G, Singh BN, Singh HB. Antioxidant and free radicalscavenging activities of seeds and agri-wastes of some varieties of soybean (Glycine max). Food Chem. 2007;104(2):783-90.

7. Kannan RRR, Arumugam R, Anantharaman P. In vitro antioxidant activities of ethanol extract from Enhalus acoroides (L.F.) Royle. Asian Pac J Trop Med. 2010;3(11):898-901.

8. Middleton EJ, Kandaswami C, Theoharides TC. The effects of plant flavonoids on mammalian cells: implications for inflammation, heart disease, and cancer. Pharmacol Rev. 2000:52:673-751.

9. Pietta P. Flavonoids as antioxidant. J Nat Prod. 2000;63:1035-42.

10. Hossain MM, Kawamura Y, Yamashita K, Tsukayama M. Microwave-assisted regioselective synthesis of natural 6-prenylpolyhydroxyisoflavones and their hydrates with hypervalent iodine reagents. Tetrahedron. 2006;62:8625-35.

11. Di Pietro A, Conseil G, Peres-Victoria JM, Dayan G, Baubichon-Cortay H, Trompier $\mathrm{D}$, et al. Modulation by flavonoids of cell multidrug resistance mediated by P-glycoprotein and related ABC transporters. Cell Mol Life Sci. 2002;59:307.

12. Barron D, Di Pietro A, Dumontet C, Mclntosh DB. Isoprenoid flavonoids are new leads in the modulation of chemoresistance. Phytochem Rev. 2002;1:325.

13. Ahmed T, Uddin MN, Ahmed S, Saha A, Farhana K, Rana MS. In vitro evaluation of antioxidant potential of Artocarpus chama Buch. fruits. J App Pharm Sci. 2012;2(10):075-80

14. Noguchi N, Niki E. In: Papas MP, editor. Diet Nutrition and Health. 20th ed. Florida: CRC Press; 1999

15. Yusuf M, Begum J, Hoque MN, Chowdhury JU. Medicinal Plants of Bangladesh. Chittagong: BCSIR; 2009. p. 794.

16. Ghani A. Medicinal Plants of Bangladesh with Chemical Constituents and Uses. 2nd ed. Dhaka: Asiatic Society of Bangladesh; 2003. p. 603.

17. Ghani A. Practical Phytochemistry. 1st ed. Dhaka: Parash Publishers; 2005. p. 12-8.

18. Braca A, Tommasi ND, Bari LD, Pizza C, Politi M, Morelli I. Antioxidant principles from Bauhinia terapotensis. J Nat Prod. 2001;64:892-5. 
19. Oyaizu M. Studies on products of browning reactions. Antioxidative activities of products of browning reaction prepared from glucosamine. Jpn J Nutr. 1986;44:307-15.

20. Resat A, Kubila G, Mustafa O, Saliha EK. Novel Total Antioxidant Capacity Index for Dietary Polyphenols and Vitamins C and E, Using Their Cupric Ion Reducing Capability in the Presence of Neocuproine: CUPRAC Method. J Agric Food Chem. 2004;52:7970-81.

21. Alisi CS, Onyeze GOC. Nitric oxide scavenging ability of ethyl acetate fraction of methanolic leaf extracts of Chromolaenaodorata (Linn.). Afr J Biochem Res. 2008;2(7):145-50.

22. Prieto P, Pineda M, Aguilar M. Spectrophotometric quantification of antioxidant capacity through the formation of a phosphomolybdenum complex: Specific application to the determination of vitamin E. Anal Biochem. 1999;269:337-41.

23. Yu L, Haley S, Perret J, Harris M, Wilson J, Qian M. Free radical scavenging properties of wheat extracts. J Agric Food Chem. 2002;50:1619-24.

24. Chang $\mathrm{C}$, Yang $\mathrm{M}$, Wen $\mathrm{H}$, Cheru J. Estimation of total flavonoids content in propolis by two complementary colormetric methods. J Food Drug Anala. 2002;10:178-82

25. McLaughlin JL. Bench-top Bioassays for the Discovery of Bioactive Compounds in Higher Plants. Brenesia. 1991;34:1-14.

26. Meyer BN, Ferringm NR, Puam JE, Lacobsen LB, Nichols DE, MeLaughlin JL. Brine shrimp: a convenient general bioassay for active constituents. Planta Med. 1982;45:31-2.

27. Bauer AW, Kirby WM, Sherris JC, Turck M. Antibiotic susceptibility testing by a standardized single disk method. Am J Clin Pathol. 1966;45:493-6.

28. Drew WL, Barry AL, Toole R, Sherris JC. Reliability of the Kirby-Bauer disC diffusion method for detecting methicillin-resistant strains of Staphylococcus aureus. Appl Microbiol. 1972;24(2):240-7.

29. Akindele AJ, Adeyemi OO. Anti-inflammatory activity of the aqueous leaf extract of Byrsocarpus coccineus. Fitoterapia. 2007;78(1):25-8.

30. Koster R, Anderson M, De Beer EJ. Acetic acid for analgesic screening. Fed Proc. 1959;18:412-8.

31. Blois MS. Antioxidant determinations by the use of a stable free radical. Nature. 1958;181:1199-200.

32. Gordon $\mathrm{MH}$. The mechanism of antioxidant action in vitro. In: Hudson BJF, editor. Food antioxidants. London: Elsevier Applied Science; 1990. p. 1-18.

33. Vinson JA, Hao Y, Zubic SK. Food antioxidant quantity and quality in foods Vegetables. J Agric Food Chem. 1998;46:3630-4.

34. Joseph S, Sabulal B, George V, Smina TP, Janardhanan KK. Antioxidative and Antiinflammatory activities of the chloroform extract of Ganoderma lucidum found in south India. Sci Pharm. 2009;77:111-21.

35. Boone CW, Kelloff GJ, Malone WE. Identification of candidate cancer chemopreventive agents and their evaluation in animal models and human trials: A Review. Cancer Res. 1990;50:2-9.

36. Frankel EN, Waterhouse AL, Teissedre PL. Principal phenolic phytochemicals in selected California wines and their antioxidant activity inhibiting oxidation of human low-density lipoprotein. J Agric Food Chem. 1995;43:890-4.

37. Uritani I, Garcia W, Mendoza EMT. Postharvest biochemistry of plant food- materials in the tropics. 1st ed. Tokyo: Japan Scientific Societies Press; 1994. p. 241-51.

38. Benavente-Garcia O, Castillo J, Marin FR, Ortuño A, Del-Rio JA. Uses and properties of Citrus flavonoids. J Agric Food Chem. 1997;45:4505-15.

39. Tona L, Kambu K, Ngimbi N, Cimanga K, Vlietinck AJ. Antiamoebic and phytochemical screening of some Congolese medicinal plants. J Ethnopharmacol. 1998;61:57-65.

40. Zaninir JC, Medeiros YS, Cruz AB, Yunes RRA, Calixto JB. Action of compounds from Mandevilla velutina on croton oil induced ear oedema in mice; a comparative study with steroidal and non-steroidal antiinflammatory drugs. Phytother Res. 1992;6:1-5.

41. Jm K, Ma R, Zhu D, Yan Y. Blood-activating and anti-inflammatory actions of Polygala fallax. Zhong Yao Cai. 2003;26:268-71.

42. Bradley PP, Priebat DA, Christensen RD, Rothstein G. Measurement of cutaneous inflammation: estimation of neutrophilcontent with an enzyme marker. J Invest Dermatol. 1982;78:206-9.

43. Ahmed F, Hossain MH, Rahman AA, Shahid IZ. Antinociceptive and sedative effects of the bark of cerbera odollam Gaertn. Ori Pharm Exp Med. 2006:6:344-8.

44. Ronaldo AR, Mariana LV, Sara MT, Adriana BPP, Steve P. Involvement of resident macrophages and mast cells in the writhing nociceptive response induced by zymosan ad acetic acid in mice. Eur J Pharmacol. 2000;387:111-8.

45. Hossain MM, Ali MS, Saha A, Alimuzzaman M. Antinociceptive activity of whole plant extracts of Paederiafoetida. Dhaka Univ J Pharm Sci. 2006;5:67-9.

\section{Submit your manuscript to a SpringerOpen ${ }^{\circ}$ journal and benefit from:}

- Convenient online submission

- Rigorous peer review

- Immediate publication on acceptance

- Open access: articles freely available online

- High visibility within the field

- Retaining the copyright to your article

Submit your next manuscript at $>$ springeropen.com 